The following corrections may also be noted :

p. I33, line I7 from top, for "cuticle" read cortex.

p. I38, last line, for "externally" read extremely,

p. I33, line I9 from bottom, for "acutifolium" read acutiforme.

p. ${ }^{3} 35$, line 9 from bottom, for "ta.b." read $t a b$.

p. I37, line I 7 from bottom, insert a hyphen after grayish. or.

p. I89, line I5 from bottom, for "looser and" read looser

p. 218 , line 14 from top, for "ranged" read ringed. lata.

p. 223 , line I4 from bottom, for "serrulatum" read serruimen.

p. 226, line I4 from bottom, for "specimens" read a spec-

Neuruppin, Germany, Feb. 6, I89o.

\title{
Some recent observations on black-rot of the grape.
}

\section{B. T. GALLOWAY.}

During the summers of 1889 and 1890 we made a series of experiments, with a view of determining, if possible, the relationship existing between the so-called Phyllosticta labrusca Thum., which occurs on the leaves of the cultivated and wild grapes, the Phyllosticta ampelopsidis E. \& M., occurring on Ampelopsis quinquefolia and A. Vietchii, and the various forms attacking the fruit of the cultivated grape, which, as shown by Scribner and Viala ${ }^{1}$, are stages of one fungus, namely Lastadia Bidwellii, of Viala and Ravaz.

Without going into details of the work, we will say that something like 200 inoculations of the berries of a dozen or more varieties of cultivated grapes were made from pycnidia-spores obtained from the leaves of Ampelopsis and Vitis; but in no case did we succeed in producing any of the Lastadia forms, or for that matter any disease whatever. Berries of all ages were used in the experiments; some were inoculated as they hung on the vines, and were protected from outside contamination by paper bags; others were brought into the laboratory, and, after being inoculated with germinating spores from the leaves, were placed in damp

1Black-rot, Bulletin No. 7. Section Vegetable Pathology, U. S. Department of Agricul-
ure, 1888, 
chambers and kept there for a week; a large number of clusters were brought into the laboratory, and, after being inoculated, were placed in the incubator, where a constant temperature of $32^{\circ} \mathrm{C}$. prevailed. At the expiration of four days the berries in the incubator would usually turn brown, but microscopic examination revealed the fact that this was due to the attacks of moulds and bacteria.

In the majority of cases the inoculations were made by teasing up a bit of the affected leaf in water, and after making sure, by means of the microscope, that this water contained spores, it was allowed to stand from twenty-four to thirty-six hours, or until the spores had germinated. The water was then spread on the berries with a camels hair brush. In addition to this method, others, such as using spores fresh from the leaf, and spores sown in 3 per cent. solutions of grape sugar, were tried. Various degrees of light from absolute darkness to bright sunshine were also brought into play, all with the same result. To test the matter another way, sowings of pycnidia-spores from the berries were made on the leaves, the result being purely negative in every case. Pycnidia-spores from the berries were also sown on the berries, but in no case did we succeed in obtaining any definite results from this source.

The foregoing experiments were made in 1889 . This season the same ground was gone over with practically the same results as those already noted. In addition, however, a series of inoculations were made with the ascospores of the Lastadia, and, as these yielded more definite results, we shall give an account of the work in full.

In the fall of 1889 a large quantity of berries which had succumbed to the attacks of black-rot a few months before were collected from the vines growing in the grounds of the United States Department of Agriculture. These berries were placed in a corner of my garden where they were left fully exposed to the weather until the middle of May of this year. Frequent microscopic examinations were made in the meantime for the purpose of determining the date of the first appearance of mature ascospores, which, we may as well add here, was the 15 th of February. From this time on the ascospores were found in more or less abundance, the maximum number being reached about the middle of May, after which they began to be less numerous and finally disappeared altogether by the 20 th of June. At no time were pycnidiaspores found in any of the berries. 
Experiment No. I.-On the $25^{\text {th }}$ of April a potted plant of Ampelopsis quinquefolia, which had been in the greenhouse for four months, was removed to the open ground and planted on the spot where the diseased berries had lain all winter. The vine, which was about two feet long, was spread out on the ground and a large number of grapes containing ascospores were placed on the leaves. For the next twelve days there were frequent rains, which, with the warm weather prevailing at the time, afforded just the conditions necessary for the rapid development of the fungus. On the roth of May a number of the Ampelopsis leaves showed the characteristic spots of the Phyllosticta, and an examination of these a few days later revealed the presence of pycnidia and pycnidia-spores. The spores and pycnidia did not differ in any respect from those formed in the usual way. Another plant of Ampelopsis quinquefolia about thirty feet distant from the first served as a control experiment. No spots appeared on this plant at all.

Experiment No. 2.-May ro two pot grown plants of Norton's Virginia grape having four well formed leaves were planted in my garden and were immediately covered with bell jars. May i I the bell jars were removed and about a handful of the old grapes containing ascospores were placed on the leaves, the jars being immediately replaced and not disturbed again for a month, except to water the plants, the latter being done every two days. At the expiration of twenty-five days both of the plants treated as above showed a number of leaf spots, which upon examination proved to be typical Phyllosticta discolorations bearing upon their surfaces pycnidia, which contained the usual shaped spores. A dozen potted grapes fifteen feet distant remained perfectly healthy throughout this period.

Experiment No. 3.-Two plants of Muscat of Alexandria grape growing in the green-house were covered with bell jars. On May 20 several bunches of diseased berries obwered from the same source as in the preceding experiments losticta five days later are showing on a number of the leaves, and by the futer a number of the leaves were almost destroyed tender, fungus. The leaves of the Muscat, being thin and instea, seem to succumb very readily to the disease, which All other forming definite spots involves the whole leaf. Experiment No. 4.- May 25 four leaves of a house grown 
Muscat vine were inoculated with pycnidia-spores obtained from another house grown Muscat and immediately covered with a bell jar. The spores were obtained in the usual way by teasing up a bit of the affected leaf in distilled water. In ten days the inoculated leaves were all affected. The leaves of one of the control plants also showed the characteristic spots of the Phyllosticta, which fact throws a doubt on the whole experiment. Unfortunately, we were not able to repeat this trial, as no plants suitable for the purpose could be obtained.

Summing up briefly the positive results of these investigations, we have the following:

I. Two hundred or more inoculations of the grape berry with pycnidia-spores from the leaves of Vitis and Ampelopsis produced no effect whatever.

II. The same number of inoculations of the leaves of Vitis and Ampelopsis with pycnidia-spores from the berries of the grape gave the same results as I.

III. Fifty or more inoculations of the berries with pycnidia-spores from the berries yielded the same results as and II.

IV. Inoculation of Ampelopsis leaves with ascospores from grape berries resulted in the formation of typical Phyllosticta ampelopsidis spots, pycnidia and spores at the expiration of fifteen days.

V. Inoculations of grape leaves with ascospores from the berry produced Phyllosticta labruscæ spots, pycnidia and spores in twenty-five days.

We have no reason to doubt the genuineness of the results obtained in the case of IV and V, first, because the old berries, so far as could be determined by microscopic examination, contained no other reproductive bodies but the ascospores. and, second, an examination of the water found on the leaves after a rain revealed only ascospores, and these in variols stages of germination. So far as we know no other attemp? of this kind has been made to establish the identity of the various forms here discussed, excepting that by Viala in France in $1888 .^{2}$ In May of that year, according to Viala? published statement, the ascospores of the black-rot fung were sown on healthy grape leaves still on the vine. In froll eight to twelve days the characteristic spots and pustules of the Phyllosticta appeared. Prof. Viala does not say how the inoculated leaves 2 Comptes Rendus, June 18th, 1888, p. 1711, Recherches experimentales sur les mas is
de la vigne. 
nor does he mention any control plants used in the experiment.

If it is true, as the experiments here recorded would seem to indicate, that the ascospores are the main source of infection, and that the spores from the Phyllosticta forms on the leaves of Vitis and Ampelopsis will not grow on grape fruit, the matter is one of considerable practical importance. This part of the subject, however, we shall not touch upon here, our purpose being merely to record the facts, leaving the practical questions involved to be settled by field experiments, which we may add are now under way.

Department of Agriculture, Washington, D.C.

\title{
Notes on North American Umbelliferæ. II.
}

\author{
JOHN M. COULTER AND J. N. ROSE.
}

(WITH PLATE XV.)

The first paper of this series was published in this journal of November, I889. The present paper consists chiefly of a report on Mr. J. Donnell Smith's Guatemalan collection.

Hydrocotyle leucocephala Cham. \& Schl. No. ${ }^{1776}$ of Smith from Coban Department, Alta Vera Paz, alt. 4,300 feet, April r 889 ; also 74 of Türckheim from near the same locality, May 1879. Although Mr. Hemsley says that he has found no publication of this species from Mexico, these specimens seem to accord very well with the description.

Hydrocotyle Bonariensis Lam., var. Texana n. var. peltates and peduncles 15 to $20 \mathrm{~cm}$. long; leaves orbicularpeltate, not notched at base, 12 to 15 -nerved: inflorescence 5 to $10 \mathrm{~cm}$. long, irregularly or 3 to 5 -umbellately branched : pedicels $3 \mathrm{~mm}$. long or less : fruit obtuse at base, $2 \mathrm{~mm}$. long by $3 \mathrm{~mm}$. broad.-Texas, i888, G. C. Nealley. Probably collected along the sea-coast, as, otherwise, its occurrence within our borders would be hard to explain. The species is only known from southern Mexico and South America.

Hydrocotyle PROLIFERA Kell. This species is mentioned by Hemsley in Suppl. Biol. Cent. Amer., and to it which rerred Coulter's, and Parry \& Palmer's specimens, Smith in the body of the work are placed under $\mathrm{H}$. interrupta. 


\section{$2 \mathrm{BHL}$ Biodiversity Heritage Library}

Galloway, B. T. 1890. "Some Recent Observations on Black-Rot of the Grape." Botanical gazette 15(10), 255-259. https://doi.org/10.1086/326574.

View This Item Online: https://www.biodiversitylibrary.org/item/90530

DOI: https://doi.org/10.1086/326574

Permalink: https://www.biodiversitylibrary.org/partpdf/221928

\section{Holding Institution}

Missouri Botanical Garden, Peter H. Raven Library

\section{Sponsored by}

Missouri Botanical Garden

\section{Copyright \& Reuse}

Copyright Status: Public domain. The BHL considers that this work is no longer under copyright protection.

This document was created from content at the Biodiversity Heritage Library, the world's largest open access digital library for biodiversity literature and archives. Visit BHL at https://www.biodiversitylibrary.org. 